\title{
The Dialogues between Content and Language: Cautions and Challenges in the Emergence of a Bilingual Education Program
}

\author{
Los diálogos entre el contenido y la lengua: \\ cautelas y retos en la emergencia de un programa \\ de educación bilingüe
}

\author{
Carlos Eduardo AGUILAR CORTÉS \\ Liceo Hermano Miguel La Salle, Bogotá, Colombia \\ ce.aguilar@uniandes.edu.co
}

\author{
Nelson Eduardo ALZATE B. \\ Liceo Hermano Miguel La Salle, Bogotá, Colombia \\ nealzate@redp.edu.co
}

\begin{abstract}
This paper presents a set of ideas about the basics for developing interdisciplinary dialogues between content (science) and language (English) in bilingual educational processes, under the premise that a satisfactory relationship between those elements help guarantee successful content-based instruction (CBI) in its form known as sheltered instruction. Additionally, a practical example (based on a science curriculum) is presented to demonstrate some principles that inform approaches to teaching such content. Finally, based on the authors' interdisciplinary work and pedagogical experiences, some recommendations on teaching content and language in bilingual settings are presented in the form of cautions (a balance of actions) and challenges (prospects).
\end{abstract}

Keywords: CLIL (content and language integrated learning); CBI (content-based instruction); SIOP (sheltered instruction observation protocol); science; interdisciplinarity.

\section{Resumen}

Este artículo presenta un conjunto de ideas fundamentales para llevar a cabo diálogos interdisciplinarios entre contenido (ciencias naturales) y lengua (inglés) en procesos de educación bilingüe, bajo premisa de que un vínculo satisfactorio entre ambos elementos ayuda a garantizar una instrucción basada en contenidos (CBI) exitosa, particularmente, en su forma de instrucción amparada. En adición, un ejemplo práctico (basado en un currículo de ciencias naturales) se presenta para demostrar algunos principios que dan cuenta de algunos enfoques para enseñar dicho contenido. Finalmente, con base en el trabajo interdisciplinario y la experiencia pedagógica de sus autores, se presentan algunas recomendaciones sobre la enseñanza de contenido y lengua en ambientes bilingües, a manera de cautelas (balance de acciones) y retos (prospectivas).

Palabras clave: AICLE (aprendizaje integrado de contenidos y lenguas extranjeras); CBI (instrucción basada en contenidos); SIOP (protocolo de observación de instrucción amparada); ciencias naturales; interdisciplinariedad.

Received: 2015-01-13 / Sent for peer review: 2015-01-13 / Accepted by peers: 2015-03-14 / Approved: 2015-04-16

To reference this article / Para citar este artículo

Aguilar Cortés, C. E., \& Alzate B., N.E. (2015). The dialogues between content and language: Cautions and challenges in the emergence of a bilingual education program. Latin American Journal of Language Integrated Learning, 8(2), 161-183. doi:10.5294/laclil.2015.8.2.5 


\section{INTRODUCTION}

The last two decades in Colombia have been marked by a growing interest in developing perspectives in the field of bilingual education, particularly Spanish-English. This may be a consequence of the bilingual education initiatives presented by Colombian government entities, the most representative of these in recent times being the National Bilingual Education Program 2004-2019 presented by the Ministry of Education of Colombia (Truscott de Mejía, López Mendoza, \& Peña Dix, 2011). Thus, most schools, sooner or later, have introduced their own answers to the challenges that coping with foreign language teaching and learning represents - and accordingly, researchers have reported on various valuable experiences concerning topic. The Liceo Hermano Miguel La Salle (LHEMI La Salle) in Bogotá has been no exception to this rule, and the arguments in this paper are derived from experiences at that institution.

The idea to start a Bilingual Education Program (BEP) at the LHEMI La Salle appeared in 2009, when it was decided that the school's English language instruction program must be intensified so as to provide the kind of cutting-edge education that the Lasallian tradition has always promoted and-at the same time- - to fulfill the expectations of the population that the school serves. The particular way in which bilingual education was implemented through the CBI (content-based instruction) approach, in the specific tradition known as Sheltered Instruction (Brinton, Snow, \& Wesche, 1989; Stryker \& Leaver, 1997) in two core subjects: English language arts and science. ${ }^{1}$

During the last five years, the experience at the LHEMI La Salle derived from that initiative has passed through different stages, evolving in unexpected ways and being the responsibility of diverse actors. An account of the systematization of this experience is main

1 English language arts refers to the subject typically known as English in Colombia but, here, inspired by American standards, the subject title implies a change in how this class is conceived, oriented not only by grammatical, linguistic, and skill development but also by the learning of a foreign language as content. Thus, the curriculum includes literary and cultural references, textual and discursive typologies, and development of sociolinguistic competences. 
subject of this paper (though see further Aguilar \& Alzate, 2015). On one hand, we discuss the interdisciplinary dialogues between content (science) and language (English), focusing on ideas that inspired interaction between the school's departments of Natural Sciences and of Foreign Languages to maintain the precision of the content even as it was taught through a foreign language. Furthermore, we examine the process through which this collaboration was developed, offering some observations on teaching Science through the principles of Sheltered Instruction as proposed by Echavarría, Vogt, and Short (2013) in the SIOP (Sheltered Instruction Observation Protocol) model, providing an example of how Science can be taught in a bilingual educational setting without any loss of content or accuracy.

On the other hand, we also present some cautions and challenges derived from the experiences of implementing the BEP at the LHEMI La Salle, which may serve as warnings for others considering or enacting the implementation of similar kinds of programs, but with the emphasis that these challenges should be understood as opportunities for future improvement.

\section{AN APPROACH TOWARDS TRANSFORMATION}

The present BEP at the LHEMI La Salle is something whose development required significant efforts in terms of organization and transformation. During that process, many people contributed decisively with ideas or actions, laying the foundations of an effective implementation of English as a foreign language in the institution. In many cases, there were contrasting perspectives and disagreements on best practices, though not necessarily based on disciplinary or individual interests but rather on the future prospects of the institution as a bilingual academic setting.

Probably, one of the most significant issues arose from the decision to include English language arts and Science in the school curriculum as two new taught subjects, because the chemistry between the diverse actors involved in that interaction evolved in an exemplary 
manner. When development of these new subjects began, there was a definite air of resistance toward the idea of teaching the two subjects in the ways proposed: English, with perspective and aim that differed markedly from that of "traditional" language classes, and science through a foreign language. This was mainly because the respective teaching traditions for these two subject areas had long ago settled into their respective routines and the respective school departments, where there was little evident interest in modifying the school curricula or status quo. In addition, there was a clear feeling of uncertainty amongst the faculty of the respective departments about the way to proceed with the challenge of intensifying English, as there little in the way of explicit theoretical or practical referents were available. Nevertheless, it was at this moment - in this environment of doubt and resistancethat the dialogues between content and language began to appear.

The remainder of this paper provides the rest of the story. Yet we would reveal that a key part of that story concerns how, as the school was facing a transformation in the ways that English and science were taught, everything changed dramatically when the actors involved became inspired by one particular idea. Particularly, the people involved began to realize that it was necessary to change how everyone thought about bilingual education - at which point, many of the actors started enriching the discussion with creative ideas and proposing collaborative strategies. As a result, they soon found that they were no longer working in isolated departments and subjects, with independent objectives, but in heterogeneous fields that could unite to face a common educational challenge.

In other words, we found ourselves facing one of the principles that Morin suggests about education from complexity theory: "La réforme de l'enseignement doit conduire la réforme de la pensée et la réforme de pensée doit conduire à la réforme de l'enseignement" (1999a, p. 21). Thus, we realized that a reform of our educational traditions would similarly reform our way of thinking; and that, equally and conversely, a reform of our way of thinking would reform our 
educational traditions. Therefore, by intensifying English instruction and introducing bilingual education to our institution, we discovered new approaches to our pedagogical and disciplinary views; but, at the same time, by introducing new approaches to our pedagogical and disciplinary views, we discovered new approaches to foreign-language education. Essentially, this is the spirit that feeds the dialogues between content and language; this is the legacy to other content areas in our institution that join the BEP; moreover, we hope this offers both motivation and guidance for those seeking to implement bilingualism in schools.

\section{THE APPEARANCE OF THE INTERDISCIPLINARY DIALOGUE AND ITS CORRESPONDING STAGES}

The forgoing sections considered the role of a spirit of transformation that helped lay the foundations for the dialogues between content and language during the implementation of the BEP at the LHEMI La Salle. To expand on this discussion, we propose interdisciplinarity as a second key element to bear in mind when implementing bilingual education processes.

As we understand it, interdisciplinarity represents the opportunity to work together with people who have dissimilar disciplinary perspectives or come from diverse occupational fields with the objective of finding solutions to puzzling questions, reducing the unnecessary boundaries that traditions have set around their respective fields of knowledge, and finding alternatives to go beyond the regular standards. Recalling Morin's (1999b) observations, "Si nous voulons une connaissance pertinente, nous avons besoin de relier, contextualiser, globaliser nos informations et nos savoirs, donc de rechercher une connaissance complexe" (p. 456), this suggests that, if we want to reach a state of knowledge that fits our contemporary needs and expectations, we have to find ways to work this out. We need to seek connections between diverse disciplines to corral scattered pieces of information, bringing objects back into their contexts, and recogniz- 
ing the tensions between local and global perspectives as reciprocal and complementary. In short, we have to accept what the Morin calls the challenge of thinking complexly if we want to reach goals that involve actual transformations in the field of education.

In our case, the dialogues that we present in this text represent the form in which we have accepted that challenge in the BEP at the LHEMI La Salle; these interdisciplinary conversations involve the transformation of an educational situation and the interconnection of efforts, ideas, and actions. Having said that, however, let us clarify that the dialogues between content and language in the development of the BEP were focused in two points in the process. The first was the English Intensification Program (EIP), which appeared in 2009 when it was decided to intensify English Language Learning (ELL) at the school; the second was the Bilingual Education Program (BEP) itself, which formally began in 2012 (and continues to this day). Moreover, three main actions supported the development of the BEP: first, a consultancy process on the EIP (Rodríguez, 2012); second, the design of a Bilingual Education Policy for the school (Liceo Hermano Miguel La Salle, 2013); and third, the introduction of additional content subjects (including social studies, ethics, and art) to further reinforce ELL in the school.

On these bases, we can briefly portray the dialogues that took place in four stages across the implementation of first the EIP (two of these stages) and then the BEP (two further stages). We identify the first stage as traditional, as there was absence of initiatives or additional needs, and any idea associated with a change in the way English was taught and learned was widely disregarded. The second stage we identify as intuitive, because there was a decision to make some changes in the curricular design and, though it allowed more hours of instruction in foreign language by teaching English language arts and science, this decision was made without much prior thought or discussion. Additionally, as a consequence of the lack of involvement of some actors in the experience and the blurry theoretical and practical 
support received, there was some resistance at this stage toward the idea of transformation, and an atmosphere of uncertainty about the future of the proposal arose. This intuitive stage could be characterized by limited awareness regarding the proposals and the prominence of separate, individualistic, disciplinary interests.

Fortunately, in the third stage did more to foster the progress of the BEP; nevertheless, we designate it as tense. At this point, experiences in the EIP had been accumulating for approximately two years, and some of the staff in charge of teaching science and English language arts (from the departments of Natural Sciences and of Foreign Languages, respectively) began to realize that it was much better to work together to strengthen both of their subjects. Slowly, an initially thin and weak, but refreshing, flow of conversation, motivated by limited awareness but coexistent interests, began to emerge. At this stage, both disciplines were preparing for more robust future interactions, gaining independent awareness of the methods and contents that each discipline used and promoted, but they were not yet working together to configure pedagogical knowledge about practices as a team.

The fourth stage we call authentic, and it is what made the writing of this paper possible, because in it the people responsible for administering and teaching science and English language arts became more than conscious of each other's existence but also found common academic interests, mutual learning opportunities, and reciprocal didactic development. One mechanism that helped overcome the limitations that previously dogged the BEP's development was the organization of interdisciplinary discussion sessions in which dialogue was established by members of both the Natural Sciences and the Foreign Languages departments. These sessions were mediated by the school's Bilingual Education Consultant and oriented toward the study and creation of a proposal of curricular design and establishment of methodological considerations for the science subject that maintained not only all the accuracy of the discipline (content) but also consciousness of 
the language needs. Through these sessions, perhaps more than any other part of the process, actors from different disciplines came to understand that disciplinary differences could be positive aspects in that they ultimately foster respect for others' ideas and can be taken advantage of to a achieve a particular common goals.

The authentic stage is characterized by interdisciplinary interaction and demonstrates how transformation in how the actors conceive of bilingual education can be fostered. In addition, this stage was marked by the conscious implementation of Sheltered Instruction in as proposed in the Sheltered Instruction Observation Protocol (Echavarría et al., 2013), together with the use of other theoretical and practical considerations derived from the disciplines involved.

Figure 1. Stages illustrating emergence of dialogues between content and language

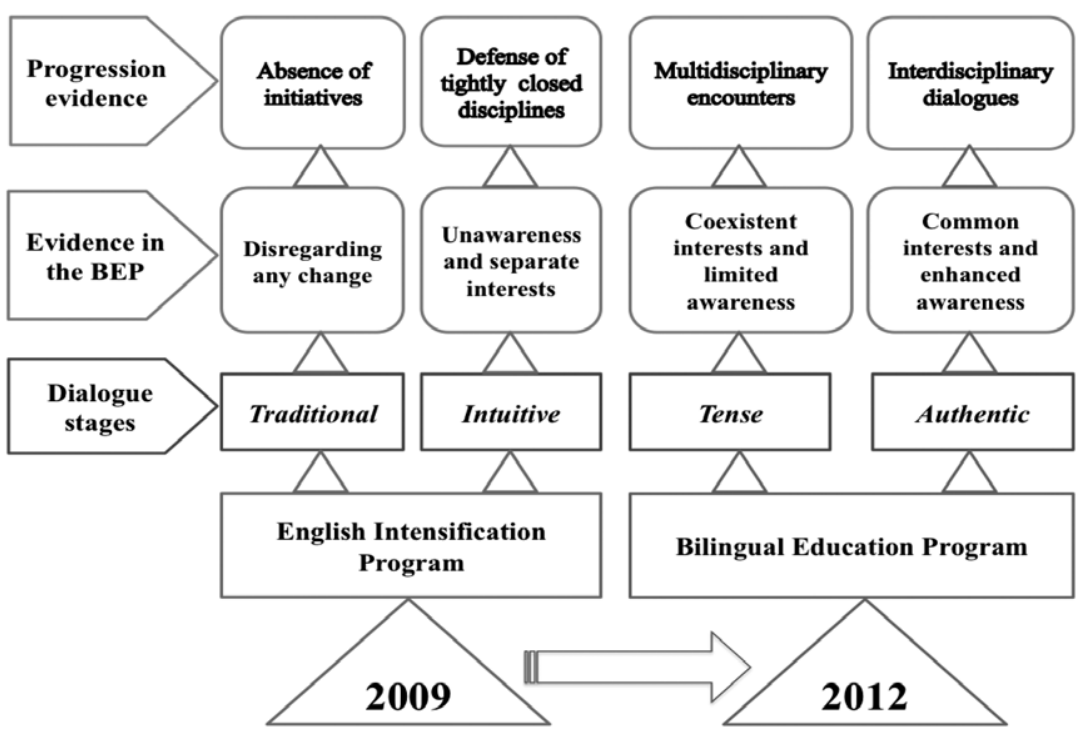

In hindsight, it is evident that the bilingual education process implemented the LHEMI La Salle could have taken less time if interdisciplinary dialogues had been recognized and promoted earlier, as all the actors involved could have spent less time trying to defend their disciplines and resolved their conflicts more rapidly. 
Nevertheless, all aspects of the process that unfolded contributed to the ultimately successful implementation of the BEP. Accordingly, when planning similar bilingual educational programs, we would recommend that the agenda include a prospective plan with stages that attend to an exploration of current theory and research on bilingual education, the recognition of other meaningful experiences, procedural intensification of language, academic discussion about the subject that may be most aptly taught in English (or another additional language), and — last but not least_-dialogue between the actors involved mediated by appropriate methodology and common interests. Furthermore, the experiences discussed in this paper show the value of taking interdisciplinarity into account when introducing bilingual education in particular settings, alongside established theories and methodologies - as, in this specific case, the Sheltered Instruction framework in relation to CBI. This aspect is further defined and expanded in the subsequent section.

\section{INTERDISCIPLINARY PERSPECTIVES TO LAY THE FOUNDATIONS FOR BILINGUAL EDUCATION}

There was a point in the implementation of the BEP at the LHEMI La Salle when it became clear that it was necessary to adopt specific approaches to teaching foreign languages, the most convincing of which appeared to be CBI. This approach seemed closely aligned to the school's intentions, and it provided those responsible for the project with theoretical and practical foundations for its further development. A particularly appealing aspect of the CBI approach was that it "implies the total integration of language learning and content learning” (Stryker \& Lou, 1997, p. 5). Nevertheless, in researching this approach we realized there were a number of variants of CBI, and thus defining a simple set of foundations was no easy task. Each variant approach was potentially useful in accelerating acquisition of language while learning content, developing cross-cultural sensitivity and having an enjoyable experience (Stryker \& Lou, 1997). 
Ultimately, in for our specific case, we chose Sheltered Instruction as our program's CBI framework because it represented a cross-curricular perspective, suggesting recognition of content and the precedence of academic language over isolated development of the foreign language. Moreover, the Sheltered Instruction approach proposes a number of specific techniques to help make content understandable in the target language, it set clear objectives according to age and grade of students, it adapted content to the cognitive, cultural and linguistic development of the learners, and it proposed the participation of students as agents of their own learning processes (Echavarría et al., 2013). In addition, we chose Sheltered Instruction because it provided a broad framework for both immediate and future opportunities; as noted by Short, Vogt, and Echavarría (2008), "sheltered instruction is provided to classes composed entirely of English language learners. In others, a mix of native and nonnative English speakers may be present. Bilingual, ESL or content teachers may be instructors for these classes" (p. 12). However, the aspect of Sheltered Instruction that was most critical in persuading us to adopt it can be summarized in the following statement:

Sheltered instruction plays a definite role in a variety of educational program designs. It may be part of a content-based ESL program, a late-exit bilingual program, a newcomer program, or a dual language program. Any program where students are learning content through a nonnative language should utilize the sheltered instruction approach. (Short et al., 2008, p. 12)

Furthermore, as dialogues between content and language strengthened, we decided to be more specific and use Sheltered Instruction Observation Protocol (SIOP). In this, we found a detailed framework and protocol that answered some of our questions about how to teach more effectively, as well as some specific methodological procedures to articulate content, language, cognition, and culture. A number of addition complementary reasons influenced our adoption of SIOP (Echavarría, Vogt, \& Short, 2013): 
- it is a model that has methodological relevance across the curricula in almost every subject (such as social studies, math, science, and English language arts).

- it can be applied in all school grade levels, with supporting materials available from the its creators.

- it encourages a high level of student engagement by regulating interaction and recognizing different learning styles.

- it suggests usage of a wide range of supplementary resources to complement or modify original materials in order to enhance learner comprehension.

- it recommends continuous training on test-taking skills as well as reading and writing proficiency.

- it establishes a set of instruments and scales to observe and accompany the actions of teachers, administrators and trainers.

From these perspectives, it might seem that the theoretical framework and methodological considerations for the implementation of the BEP should be complete. However, in the course of our interdisciplinary dialogues, we found that various ideas derived from the teaching and didactics of Natural Sciences-not related to ESL traditions, and introduced by science or chemistry experts-could improve our application of SIOP in the BEP. As an practical demonstration, we provide an example that shows how concepts drawn from how Science is taught in the first language (L1), long used and proved, can be very useful, as well as how dialogues between content and language have unfolded in practice as complementary efforts that cultivate different interdisciplinary directions.

\section{EXAMPLE DRAWN FROM SCIENCE TEACHING}

The example presented in this section is based on a science subject topic, the cell. This is a concept revisited multiple times and at different levels of complexity throughout primary and secondary education, though we have found many students struggle to understand it completely, and its scientific implications can provide difficulties. For the 
purposes of this paper, this example provides a practical demonstration of how the ideas and specific experiences of the BEP implementation at the LHEMI La Salle were put into practice, and how interdisciplinary dialogues between content and language can have tangible results. Equally, it is also intended to show how science can be taught in in a foreign language (in this case, English) without compromising the subject's scientific, conceptual, and experimental nature.

More specifically, the example demonstrates how a Science teacher can integrate certain conceptual and procedural elements of the Natural Sciences into their practice through ideas derived from the active learning method (Huber, 2008). These ideas are part of the conceptions in which Natural Sciences are constructed from empirical deductions; that is, abstractions (concepts and models) and theories that are born from observations and interpretations of the physical world in three levels: macroscopic, sub-microscopic, and symbolic (Johnstone, 2006). The macroscopic describes the observable reality and is related to daily experiences and perceptible phenomena; the sub-microscopic represents the recreation of theoretical models from the capability of abstraction and imagination; and the symbolic refers to the definition of symbols and concepts. It should be clarified that science teaching can favor any of the levels just described at different points, but balance among them must be maintained if we wish to keep a connection between theoretical knowledge and the real, everyday world (Nakamatsu, 2012).

\section{Teaching the cell}

The example on teaching the cell can begin with a question framed (for this case) for the context of a $4^{\text {th }}$-grade science class: "How can the cell membrane block the passage of water by means of its own structure?" As the topic is so wide, we focus interest in this example on the vegetable cell. Then particular learning objectives can be established; for content, "analyzing the properties that make the membrane cell semi-permeable and selective"; and for language, "using past tense statements to explain what 
happened in the interactive demonstration about the properties of the cell membrane". Both those objectives take into account the ideas that come from Sheltered Instruction and the SIOP model to prepare a lesson.

Next, the example proceeds with an initial approximation to build background and provide some comprehensible input. From the sub-microscopic level (Johnstone, 2006), an illustration of the cell and the membrane is presented, with the objective of modeling its structure and favoring recognition of the function that it carries out as a part of the cell. Based on that recognition, using certain strategies and interactions as proposed by Echavarría et al. (2013) helps articulate the sub-microscopic level with the macroscopic level (Johnstone, 2006) by developing an experimental practice that allows the students to observe the phenomenon about which we want them to construct predictions, generate discussion, and begin to define some concepts based on the real, close context that we have produced. At this point, this example continues with the following steps:

1. Describing materials and procedures: In the illustration (Figure 2), there are two glasses with sand; one we will call yellow, and another we will name blue. In addition, we have glasses with water, oil, and soapy water. We will also have blue sand on a surface, to which we will add colored water drops.

Figure 2. Experimental procedure

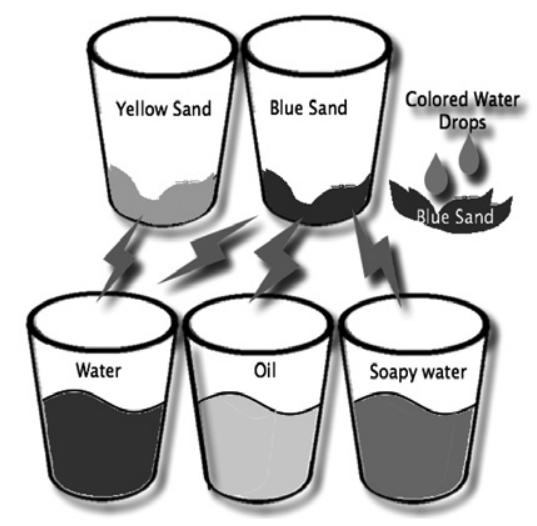


2. Guide individual and group predictions before going to the demonstration, using questions like the following (and asking for some explanation in each answer given): What occurred inside the glasses of water when we added blue and yellow sand? Why did this happen? When we changed the water for oil or soapy water, what happened? As we removed water from the containers, what shape did blue sand take? What happened with yellow sand? There was a layer of blue sand on the surface; when we added some drops of colored water, what happened? Why did it occur?

3. By formulating individual and group predictions, the students can understand that scientific activities are social practices that require interaction among peers (human beings). In that way, dialogues between the students can permit constant construction of new meanings (García, 2005). Furthermore, the process of predicting, of discussing in small groups, and of writing ideas catches the attention of the learners who are eager to see the results of the demonstration (Sokoloff, 2004).

4. Later, after doing the demonstration itself, ask the students (individually and then in groups) to contrast their previous predictions with the actual results obtained through observation demonstration and to explain the observed phenomenon.

With this experience, students have the chance to practice and apply content to change their beliefs, especially when they see the differences between their observations and the those of others. Precisely, it is this "imbalance" between the prediction and the experimental result that produces affective opportunities to learn (Huber, 2008).

Finally, the concepts "hydrophobic" and "hydrophilic" are constructed from the predictions, observations, and discussions carried out. These concepts are connected to the properties of the cell membrane that allow it to be semi-permeable and selective. It is at this point that we present the symbolic level (Johnstone, 2006) and that we expect students to recognize knowledge that is put together from the observations of the physical world, thereby contributing 
to the development of learners' confidence in their scientific skills (Sokoloff, 2004).

The ideas presented through this example are summarized in Figure 3.

Figure 3. The three conceptual levels of chemistry

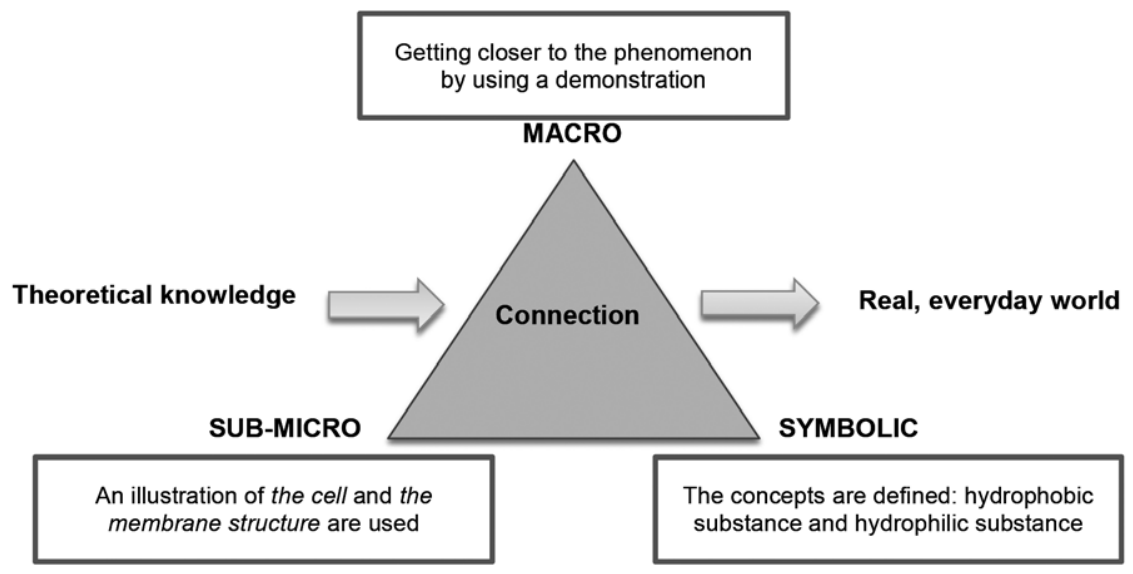

Source: Adapted from Johnstone (2006, p. 59).

It should be emphasized that the three levels have to be considered harmoniously, bearing in mind that excess in the descriptive aspect (macroscopic level) leads to memorization of properties and facts, while a disproportionate concentration on the symbolic or sub-microscopic aspects can make the content unit too theoretical or exaggeratedly abstract (Johnstone, 2006).

From the perspective of the student, the case just described, based as it is on an experiment inside the classroom, encourages observation and analysis, contrasting what has been seen with what has been already acquired in previous classes or other experiences. A learning experience of this kind can represent an opportunity to make learners confront situations in which they must observe and analyze facts, extract the essential, deduce certain ideas, and contrast these with their previous knowledge in order to stimulate intellectual 
processes which, correctly guided, can generate curiosity (Garcia, 2005). Subsequently, these points can be linked with what the SIOP model suggests as practice and application and lesson delivery.

The fact that students can perceive "science" as being composed of a set of static dogmatic paradigms, written in texts or given as final truths by scientists inside laboratories, is critical in bilingual education, because if learners cannot move beyond such an idea, they cannot understand the experimental and evolutionary character of the subject (Nakamatsu, 2012). In such a scenario, learners would rely only on memory to learn both content and foreign language, hence limiting their comprehension and restricting their cognitive development. Such a perception entails an impoverished and distorted vision of science that makes it difficult to see that it is a theoretical and practical human construction containing a universal dimension that is understandable, always changing, and that allows explanation and prediction of transformations in society that themselves can make a remarkable impact on students' lives (Garcia, 2005). That is surely what Hammond (2012) makes reference to when, with regard to teaching science in ELL lessons, he argues: “Tying Science to students' lives, incorporating their background experiences and engaging students as active learners will improve the science program for all students, while simultaneously creating a program in which ELL students can shine" (p. 228).

From the perspective of the teacher, in examples like the one presented in this paper, it is necessary to rely on what Shulman (1987) calls "content pedagogical knowledge", understood as scientific knowledge that is transformed and adapted to make it accessible, comprehensible, and motivating for learners. It demands from the teacher the ability to identify pre-concepts that are essential to integrate the topic, previous experiences and ideas, the most common conceptual errors, and the appropriateness of the concepts for the development of future topics. 


\section{CONCLUSIONS}

Based on the different considerations and perspectives presented, we argue that interdisciplinary efforts oriented towards transformation should be organized holistically; the visions of language or science must pursue one common destination that goes beyond their respective disciplinary traditions. We the example provided here serves as an example of, on one hand, interdisciplinary dialogues applied to the teaching of science in a foreign language and, on the other hand, a transformation of the ways in which scientific knowledge can be exhibited to students, as all too commonly in contemporary educational practices this rarely shows an articulation between theoretical knowledge and knowledge drawn from everyday life.

\section{Cautions and challenges}

Though our experiences highlight the advantages of the adopting the approaches suggested by and exemplified in this paper, we must also issue some cautions and identify some challenges with regard to interdisciplinarity, bilingual education, and science teaching. The cautions, based on the experiences of implementing a BEP at the LHEMI La Salle may serve as warnings for others attempting to design or implement bilingual education programs, while the challenges point towards future actions and opportunities in our specific BEP program as well as those that others may encounter in their own contexts.

\section{Cautions}

We make the following cautions, based on our experiences:

- The conception of dialogues between content and language is something that should be closely related to the creation and evolution of a bilingual education program and the establishment of a bilingual education policy in an institution.

- Bilingual education is a powerful way to discover new approaches to our existing pedagogical and disciplinary views. 
- $\quad$ As it suggested by the SIOP model's creators in the umbrella metaphor (Echavarría et al., 2013, p. 21), it is a good idea to implement complementary didactics coming from disciplinary traditions, perhaps in most cases not related to EFL or ESL approaches, as they validate and improve the procedures used to teach content and language.

- Interdisciplinarity is not only about gathering together people from different disciplines; it also implies the involvement of people playing diverse roles in schools: principals, administrators, heads of departments and teachers.

- It is vital to establish a framework within which the teaching and learning of content and languages takes place. This construction - in our case, SIOP_should align with the foundational principles of the institution in which they are implemented as they configure epistemological orientations, the curricular design, methodologies to be used, ways to assess learning, materials, and human resources.

- Besides taking into account content and language as essential components of bilingual education, it is vital to include cognitive development and intercultural awareness as complementary elements.

- Practical experiences based on pedagogical actions act as supports to the ideas that emerge from interdisciplinary dialogues between content and language, contributing to the development of more effective practices.

- $\quad$ People involved in a bilingual education program should move beyond "traditional" practices, because bilingual education is part of the answer to the challenges that contemporary society and its demands present.

- It can be effective to develop a bilingual education program that establishes science as one of its core subjects, because the experimental and practical character of the subject can support 
(and be supported) through a wide variety of bilingual education strategies.

- Science (and other subjects) can be taught in English (or other additional languages) in settings that present diverse challenges (related to human resources, content knowledge limitations, or materials) without losing the scientific, conceptual, and experimental natures of the subjects.

- Science teaching should be closely supported by observations and interpretations of the physical world in the macroscopic, sub-microscopic and symbolic levels (Johnstone, 2006); this helps guarantee more meaningful learning of the content without fear of the risks that instruction in a foreign language may involve.

\section{Challenges}

- We identify the following cautions, based on our experiences:

- The curricular design of every subject should be adjusted to form the foundation of all the teaching and leaning actions, starting with the establishment of clear content and language objectives.

- Consideration of academic and social vocabulary (BICS and CALP, as discussed by Cummins, 2000) is vital in the effective promotion of cognitive considerations regarding mental operations and expressive skills, emotional and psychomotor abilities, and local and global references.

- The curricular design should include transversal considerations about content and language between all the subjects taught as part of a particular bilingual education program.

- Spaces and times should be institutionalized to develop team-teaching and proposals that involve interdisciplinary efforts.

- Interdisciplinary dialogues are not only about gathering people from the same institution, but should ideally be inter-institutional.

- The ideas presented in this paper about teaching science can be adapted as pedagogical innovations in other subject areas, with 
the understanding that it is necessary to evaluate their theoretical and practical effects and their applications to other fields of knowledge.

- It is necessary to strengthen science teachers' own scientific literacy, because in many bilingual educational settings these teachers are not trained science pedagogy but in languages. Interdisciplinary dialogue between heads of departments and teachers can improve this issue effectively.

- The usage of Sheltered Instruction in bilingual settings and considerations of methodology and didactics coming from disciplinary views provide opportunities for L1 content teachers to plan and develop their lessons in more conscious and representative ways.

- When working with SIOP (or other similar models), it may be necessary to adjust the approaches and assumptions about teaching and learning from an ESL to an EFL context. Efforts should be directed towards the development of TWIOP model reflection and evidence.

- The example presented in this paper (using somewhat, though not entirely, arbitrarily chosen science topic: the cell), supported by observations and interpretations of the physical world at the macroscopic, sub-microscopic and symbolic levels, suggests how other disciplines/subjects such as social studies, art, math, problem solving, and ethics could cultivate fresh approaches to teaching content through a foreign language. A number of questions remain regarding bilingual content teaching in specific subject areas:

- Science: How can science be taught without losing the experimental and practical character of the subject?

- Social studies: How can we work out the tensions between what is local and what is global in terms of cultural awareness, identity, and diversity? 
- Math: How can we get rid of the fear of including logical thinking in bilingual instruction given that this aspect is highly valued and evaluated in contemporary educational systems through standardized testing?

- Spanish and literature: How can we involve Spanish (or other L1s) appropriately as vehicles of teaching and learning in bilingual settings, given that many people consider first languages or content related to them as just another "subject" and not themselves as vehicles for instruction?

- English language: How can we strengthen the idea that English language arts is a content subject and not just the traditional teaching of EFL grammar and vocabulary?

If we are to contribute to education that aligns with and meets the challenges presented by contemporary society, we have to recognize that knowledge and its development are complex constructions in constant evolution and adjustment. Thus, there is a need to promote alternative paths for teaching and learning the concepts behind objects of knowledge. Bilingual (or multilingual) education founded on content-based instructional approaches, though offering significant opportunities, also present significant challenges in their design and operationalization. The vehicle for carrying out more effective processes of transformation to answer to those challenges is, we would argue, interdisciplinarity.

\section{ACKNOWLEDGEMENTS}

This paper is based on a presentation at the 5th Biennial CLIL Symposium: New trends, challenges, and opportunities in the CLIL classroom, Universidad de La Sabana, Chía, Colombia, 12 September 2014. The ideas and example it contains are based on the systematization of experience during the development of an English Intensification Program (EIP) and Bilingual Education Program (BEP) in the Liceo Hermano Miguel La Salle in Bogotá, Colombia. 


\section{REFERENCES}

Aguilar, C. \& Alzate, N. (2015). La construcción del programa de educación bilingüe del LHEMI La Salle: Un itineario para la convergencia entre contenido y lengua extranjera. In N. A. Murcia Suárez (Ed.), Sistematización de experiencias educativas en la escuela lasallista No2 (pp. 251-273). Bogotá, Colombia: Distrito Lasallista de Bogotá. Retreived from http://www.lasalle. org.co/wp-content/uploads/2015/03/Libro_sistematización experiencias_No2_web.pdf

Brinton, D. M., Snow, M. A. \& Wesche, M. B. (1989). Content-based second language instruction. New York, NY: Newbury House.

Cummins, J. (2000). Language, power and pedagogy: Bilingual children in the crossfire. Clevedon, UK: Multilingual Matters.

Echavarría, J., Vogt, M., \& Short, D. (2013). Making content comprehensible for English learners: The SIOP Model $\left(2^{\text {nd }}\right.$ ed). Upper Saddle River, NJ: Pearson.

García Ruíz, A. \& Castro Guío, M. D. (2005). Aplicación del enfoque ciencia, tecnología, sociedad y ambiente ante problemas reales: Vertidos incontrolados de residuos. Enseñanza de las ciencias, Numero extra. Retreived from http://ddd.uab.cat/ record $/ 69217 ? \ln =\mathrm{ca}$

Huber, G. L. (2008). Aprendizaje activo y metodologías educativas. Revista de Educación, Número extraordinario, 59-81. Retrieved from http://www.revistaeducacion.mec.es/re2008_04.htm

Hammond, L. (2012). Teaching science. In L. Ferlazzo \& K. Sypnieski (Eds.), The ESL/ELL teacher's survival guide: Ready-to-use strategies, tools, and activities for teaching English language learners of all levels (pp. 223-228). San Francisco, CA: Jossey-Bass.

Johnstone, A. (2006). Chemical education research in Glasgow in perspective. Chemistry Education Research and Practice, 7(2), 4963. http://dx.doi.org/10.1039/B5RP90021B 
Liceo Hermano Miguel La Salle (2013). Política de bilingüismo 2013. Bogotá, Colombia: Liceo Hermano Miguel La Salle.

Mora, W. \& Parga, D. (2007). Tramas histórico-epistemológicas en la evolución de la teoría estructural en química orgánica. Tecné, Episteme y Didaxis, 21, 100-118.

Morin, E. (1999a). La cabeza bien puesta: Repensar la reforma, reformar el pensamiento. Buenos Aires, Argentina: Ediciones Nueva Visión.

Morin, E. (1999b). Relier les connaissances: Le défi du XXIe siècle. Paris, France: Éditions Seuil.

Nakamatsu, J. (2012). Reflexiones sobre la enseñanza de la química. Blanco y Negro, 3(2), 38-46.

Rodríguez, M. (2012). Una evaluación curricular del programa de educación bilingüe en el Liceo Hermano Miguel La Salle. Bogotá, Colombia: LHEMI La Salle.

Short, D., Vogt, M. E., \& Echavarría, J. (2008). The SIOP model for administrators. Boston, MA: Pearson.

Shulman, L. (1987). Knowledge and teaching: Foundations of the new reform. Harvard Educational Review, 57(1), 1-22.

Sokoloff, D. \& Thornton, R. (2004). Interactive lecture demonstrations. Hoboken, NJ: Wiley \& Sons.

Stryker, S. B. \& Leaver, B. L. (1997). Content based instruction in foreign language education: Models and methods. Washington, DC: Georgetown University Press.

Truscott de Mejía, A.-M., López Mendoza, A.A., \& Peña Dix, B. (2011). Bilingüismo en el contexto colombiano: Iniciativas y perspectivas en el siglo XXI. Bogotá, Colombia: Ediciones Uniandes. 